I N S T I T U T O

DE

M E D I C I N A

T R O P I C A L

$\mathrm{DE}$

SÃO PAULO

JOURNAL OF THE SÃO PAULO INSTITUTE OF TROPICAL MEDICINE

${ }^{1}$ Universidade Federal da Grande Dourados, Laboratório de Pesquisa em Ciências da Saúde, Dourados, Mato Grosso do Sul, Brazil

2Universidade Federal da Grande Dourados, Hospital Universitário, Comissão de Controle das Infecções Hospitalares, Dourados, Mato Grosso do Sul, Brazil

Correspondence to: Simone Simionatto Universidade Federal da Grande Dourados, Laboratório de Pesquisa em Ciências da Saúde, Rodovia Dourados-Itahum, KM 12, Cidade Universitária, CEP 79804970 , Dourados, MS, Brazil

E-mail: simonesimionatto@ufgd.edu.br

Received: 7 April 2021

Accepted: 12 May 2021

\section{Carbapenem-resistant Pseudomonas aeruginosa strains: a worrying health problem in intensive care units}

Gleyce Hellen de Almeida de Souza1, Luana Rossato', Gabriel Teixeira Brito', Graciela Mendonça dos Santos Bet ${ }^{1,2}$, Simone Simionatto ${ }^{(1)}$

\section{ABSTRACT}

Pseudomonas aeruginosa is one of the most common bacterium with a broad spectrum of human-associated infections. It is intrinsically resistant to many antimicrobial drugs, making carbapenems crucial in clinical management. The emergence and dissemination of carbapenemases among $P$. aeruginos a clinical isolates is a serious public health concern as it limits the options for the treatment of bacterial infections. Here, we described the molecular and epidemiological characteristics of 28 carbapenem-resistant $P$. aeruginosa strains isolated from patients hospitalized in an intensive care unit (ICU). The antimicrobial susceptibility of carbapenem-resistant $P$. aeruginosa strains was determined by broth microdilution. The presence of resistance genes was evaluated by PCR and DNA sequencing. Additionally, alterations in genes encoding $P$. aeruginosa outer membrane proteins were analyzed by PCR as well as SDS-PAGE. Clinical characteristics of the patients and the economic impact of hospitalization on the public health system were evaluated. PCR amplification showed that the $b l a_{\mathrm{KPC}-2}$ and $b l a_{\mathrm{TEM}}$ genes were identified in three isolates $(11 \%)$ and $b l a_{\mathrm{SHV}}$ gene in two isolates $(7 \%)$. Outer membrane profiles obtained by SDS-PAGE indicated that the OprD porin was either absent or was produced at very low levels. A PCR assay using oprD-specific primers failed to show the presence of mutations in this gene. P. aeruginosa strains were isolated from 28 patients, among whom $43 \%$ (12/28) had sepsis, 31\% (9/28) had respiratory failure, and $31 \%(9 / 28)$ had systemic arterial hypertension. A high mortality rate $(39 \%)$ was observed in these patients, with an average duration of hospitalization of 34.6 days and a median cost of 3.275 dollars per patient. The production of carbapenemase was not the main mechanism of resistance in these strains. All carbapenem-resistant $P$. aeruginosa were isolated from patients hospitalized in the ICU. Besides the high mortality rate, many patients remained hospitalized for several days, resulting in a high cost of hospitalization for the public health system. Therefore, the evolution of this resistance and its dissemination should be actively monitored among critically ill patients to improve their health conditions.

KEYWORDS: Healthcare-associated infections. Antimicrobial resistance. Public health. Carbapenemase.

\section{INTRODUCTION}

Pseudomonas aeruginosa is a common cause of serious healthcare-associated problems, usually causing urinary, respiratory, and bloodstream infections ${ }^{1}$. These infections can be fatal for critically ill and immunocompromised patients and are further exacerbated by antimicrobial resistance ${ }^{2}$. There is some evidence suggesting that patients who are infected by carbapenem-resistant pathogens have an increased likelihood of morbidity and mortality compared to those infected by susceptible 
pathogens ${ }^{1,3,4}$. This is probably due to the administration of antibiotics with suboptimal or no effect against these organisms ${ }^{5}$. The resistance to carbapenem in Gramnegative bacteria has become a global problem, which has driven the World Health Organization (WHO) to include carbapenem-resistant $P$. aeruginos $a$ in the list of pathogens of high priority for the research and development of new antibiotics. According to the Centers for Disease Control and Prevention (CDC), an estimated 51,000 healthcareassociated $P$. aeruginosa infections in US hospitals occur annually. More than 6,000 (13\%) of these are multidrugresistant, with about 440 deaths per year ${ }^{6}$.

In Brazil, the rate of multidrug-resistant $P$. aeruginosa in adult and neonatal ICUs increased from $35.6 \%$ to $39.1 \%$ and $18.2 \%$ to $29.3 \%$, respectively ${ }^{7}$. The impact of the resistance of $P$. aeruginosa on health systems is a major concern and it has spread across hospitals mainly due to the frequent use of carbapenems, which has been considered the only effective antibiotic against $P$. aeruginosa infections ${ }^{8}$. Recognizing the risk of resistance to carbapenem especially in the most vulnerable patients and/or the early detection of specific carbapenem-resistance mechanisms are critical to reducing the risk of mortality, length of hospitalization, and associated costs ${ }^{3,9}$. To achieve this, identification and ongoing surveillance of carbapenem-resistant Gram-negative bacteria are needed. Here, we described the epidemiological and molecular characteristics of carbapenem-resistant $P$. aeruginosa strains isolated from patients hospitalized in ICUs.

\section{MATERIALS AND METHODS}

\section{Study site and patients}

Data were collected from patients hospitalized in a public tertiary care hospital in the municipality of Dourados, Mato Grosso do Sul State, Midwest Brazil, between November 2015 and August 2016. The hospital has 237 beds, distributed across the infirmaries and the ICUs (adult, pediatric, and neonatal). The hospital serves as a tertiary referral center for 32 cities, with an average of 9,800 annual admissions. The majority of the patients lived in Dourados, while the remaining lived in the surrounding cities.

\section{Bacterial identification and susceptibility testing}

The identification of the bacterial species and the screening for antimicrobial resistance were performed by the Phoenix ${ }^{\circledR}$ Automated System (BD Diagnostic Systems, Sparks, MD, USA) according to the manufacturer's instructions. After isolation, the susceptibility profile was confirmed, and the minimum inhibitory concentrations (MICs) of the antimicrobials were determined by broth microdilution following the recommendations of the Clinical and Laboratory Standards Institute guidelines $(\mathrm{CLSI})^{10}$.

\section{PCR for resistance genes}

Carbapenemase encoding genes were investigated by the polymerase chain reaction (PCR) and DNA sequencing ${ }^{11}$, using specific primers for: (I) serino- $\beta$-lactamases $\left(b l a_{\mathrm{TEM}}, b l a_{\mathrm{SHY}}, b l a_{\mathrm{GES}}, b l a_{\mathrm{CTX}-\mathrm{M}}, b l a_{\mathrm{BES}}, b l a_{\mathrm{PER}}, b l a_{\mathrm{KPC}}\right)$; (II) oxacillinases ( $b l a_{\mathrm{OXA}-23}, b l a_{\mathrm{OXA}-24,}, b l a_{\mathrm{OXA}-48,}, b l a_{\mathrm{OXA}-51}$, $\left.b l a_{\mathrm{OXA}-58}\right)$; and (III) metallo- $\beta$-lactamases $\left(b l a_{\mathrm{IMP}}, b l a_{\mathrm{VIM}}\right.$, $\left.b l a_{\mathrm{SPM}}, b l a_{\mathrm{GIM}}, b l a_{\mathrm{SIM}}, b l a_{\mathrm{NDM}}\right)$. The PCR products were purified with the QIAquick PCR purification kit (Qiagen, Hilden, Germany) and both strands were sequenced using the Applied Biosystems 3500 genetic analyzer equipment (Applied Biosystems, Thermo Fisher Scientific, Waltham, MA, USA). The nucleotide sequences and the deduced amino acid sequences were analyzed using the Lasergene software package (DNAStar, Madison, WI, USA) and compared with the sequences available on the Internet using the BLAST tool.

\section{Porin expression and oprD mutations}

Mutations in $\mathrm{OprD}$ and its promoter region were identified by conventional PCR, and the amplicon size was analyzed by a $1.5 \%$ agarose gel electrophoresis ${ }^{12}$. The outer membrane proteins (OMPs) were isolated and visualized by sodium dodecyl sulfate-polyacrylamide gel electrophoresis (SDS-PAGE) using membrane extracts from bacteria grown in nutrient broth overnight, following which, the gels were stained with Coomassie blue. Pseudomonas aeruginosa ATCC 27853 was used as a reference strain.

\section{Clinical data}

The following data of all the patients participating in this study were recorded: demographics; location before admission; hospital course (duration); comorbidities, treatment regimens, source of infection, and outcome (recovery/death) (Table 1). Strict CDC definitions were used to determine whether an isolated organism was associated with colonization or infection. The presence of a clinical infection was determined by the medical diagnosis, and the decision to initiate antimicrobial therapy, as well as the isolation of a carbapenem-resistant $P$. aeruginosa strains, according to the following clinical criteria (sepsis, 
Table 1 - Clinical characteristics of 28 patients infected/colonized with carbapenem-resistant Pseudomonas aeruginosa strains.

\begin{tabular}{|c|c|c|c|c|c|c|c|c|}
\hline Patient & Gender & Age (years) & Clinical specimen & $\begin{array}{l}\text { Lenght of } \\
\text { stay (days) }\end{array}$ & Comorbidities & HAI & Outcome & Treatment \\
\hline 1 & $M$ & 47 & Tracheal aspirates & ND & ND & $\mathrm{C}$ & ND & ND \\
\hline 2 & $M$ & 80 & Tracheal aspirates & 30 & SAH, SEP, CARD & I & Death & $\begin{array}{c}\text { MTZ/1,500 mg/5 d } \\
\text { PIP+TAZ/13.5 g/ } 5 \mathrm{~d} \\
\text { MEM/3,000 mg/ } 6 \mathrm{~d} / 2,000 \mathrm{mg} / 18 \mathrm{~d} \\
\text { VANCO } / 2,000 \mathrm{mg} / 6 \mathrm{~d} / 1000 \mathrm{mg} / 7 \mathrm{~d} \\
\mathrm{PMB} / 50 \mathrm{mg} / 17 \mathrm{~d} \\
\mathrm{TGC} / 200 \mathrm{mg} / 11 \mathrm{~d}\end{array}$ \\
\hline 3 & $M$ & 37 & Urine culture & 38 & DM & I & Death & $\begin{array}{c}\mathrm{CRO} / 2,000 \mathrm{mg} / 4 \mathrm{~d} \\
\mathrm{LVX} / 750 \mathrm{mg} / 2 \mathrm{~d} \\
\mathrm{PIP}-\mathrm{TAZ} / 4 \mathrm{~g}+0.5 \mathrm{~g} / 3 \mathrm{~d} \\
\mathrm{PMB} / 50 \mathrm{mg} / 20 \mathrm{~d} \\
\mathrm{TEICO} / 800 \mathrm{mg} / 3 \mathrm{~d} \\
\mathrm{TGC} / 100 \mathrm{mg} / 20 \mathrm{~d} \\
\mathrm{MEM} 3 \mathrm{~g} / 26 \mathrm{~d} / 3 \mathrm{~g} / 5 \mathrm{~d}\end{array}$ \\
\hline 4 & M & 61 & Tracheal aspirates & 92 & $\begin{array}{l}\text { NEURO, CARD } \\
\text { PNA }\end{array}$ & $\mathrm{C}$ & Recovery & $\begin{array}{c}\text { MTZ/500 mg/ } 13 \mathrm{~d} \\
\text { MEM/ } 500 \mathrm{mg} / 17 \mathrm{~d} \\
\text { TEICO/ } 400 \mathrm{mg} / 3 \mathrm{~d} / 200 \mathrm{mg} / 14 \mathrm{~d}\end{array}$ \\
\hline 5 & $M$ & 17 & Tracheal aspirates & 36 & $\begin{array}{l}\text { CARD, NEURO, } \\
\text { SEP }\end{array}$ & $\mathrm{C}$ & Recovery & $\begin{array}{c}\text { AMP-SAM/1 g+ 0.5 g/ } 4 \mathrm{~d} \\
\text { CLI/ 1,200mg/5d } \\
\text { MEM/3 g/ 26d } \\
\text { VAN/ } 2 \mathrm{~g} / 36 \mathrm{~d} \\
\mathrm{PMB} / 50 \mathrm{mg} / 22 \mathrm{~d} \\
\mathrm{TGC} / 100 \mathrm{mg} / 1 \mathrm{~d} / 50 \mathrm{mg} / 2 \mathrm{~d}\end{array}$ \\
\hline 6 & $\mathrm{~F}$ & 45 & Tracheal aspirates & ND & ND & $\mathrm{C}$ & ND & ND \\
\hline 7 & $\mathrm{~F}$ & 54 & Tracheal aspirates & 42 & $\begin{array}{l}\text { DM, SAH, CARD, } \\
\text { SEP }\end{array}$ & C & Death & $\begin{array}{c}\text { MEM/3 g/ } 26 \mathrm{~d} \\
\text { VANCO } / 2 \mathrm{~g} / 8 \mathrm{~d} \\
\mathrm{PMB} / 50 \mathrm{mg} / 26 \mathrm{~d} \\
\mathrm{AMP}-\mathrm{TAZ} / 1 \mathrm{~g}+0.5 \mathrm{~g} / 1 \mathrm{~d} \\
\mathrm{LZD} / 1,200 \mathrm{mg} / 3 \mathrm{~d} \\
\mathrm{TEICO} / 800 \mathrm{mg} / 5 \mathrm{~d} \\
\mathrm{IMP}+\mathrm{CIS} / 2 \mathrm{~g} / 4 \mathrm{~d} \\
\mathrm{TGC} / 100 \mathrm{mg} / 15 \mathrm{~d}\end{array}$ \\
\hline 8 & M & 56 & Blood culture & 16 & $\begin{array}{l}\text { ALCOH, SAH, } \\
\text { CANC, TAB, } \\
\text { HEMAT, SEP }\end{array}$ & & Death & $\begin{array}{c}\text { IMP }+\mathrm{CIS} / 2 \mathrm{~g} / 4 \mathrm{~d} \\
\mathrm{FEP} / 2 \mathrm{~g} / 7 \mathrm{~d} \\
\mathrm{MEM} / 6 \mathrm{~g} / 5 \mathrm{~d} \\
\text { VANCO/ } 3 \mathrm{~g} / 1 \mathrm{~d} / 2 \mathrm{~g} / 1 \mathrm{~d}\end{array}$ \\
\hline 9 & $M$ & 84 & Catheter & 48 & HEMAT, HYPER & C & Death & $\begin{array}{c}\text { PIP+TAZ/ } 4+0.5 \mathrm{~g} / 5 \mathrm{~d} \\
\text { VAN/500 mg/ } 12 \mathrm{~d} \\
\mathrm{MEM} / 1,000 \mathrm{mg} / 7 \mathrm{~d} \\
\mathrm{TGC} / 100 \mathrm{mg} / \mathrm{d} / 50 \mathrm{mg} / 5 \mathrm{~d} \\
\text { TEICO } / 400 \mathrm{mg} / 3 \mathrm{~d}\end{array}$ \\
\hline 10 & $\mathrm{~F}$ & 24 & Secretion culture & 44 & RESP, SEP & C & Death & $\begin{array}{c}\text { MEM/ } 3 \mathrm{~g} / 14 \mathrm{~d} / 3 \mathrm{~g} / 19 \mathrm{~d} \\
\mathrm{TEICO} / 800 \mathrm{mg} / 1 \mathrm{~d} / 800 \mathrm{mg} / 8 \mathrm{~d} \\
\text { VANCO/500 mg/ } 3 \mathrm{~d} \\
\mathrm{TGC} / 100 \mathrm{mg} / 29 \mathrm{~d} \\
\mathrm{PMB} / 50 \mathrm{mg} / 17 \mathrm{~d} \\
\mathrm{IMP}+\mathrm{CIS} / 2 \mathrm{~g} / 6 \mathrm{~d}\end{array}$ \\
\hline 11 & $\mathrm{~F}$ & 26 & Urine culture & ND & NEURO, SEP & I & Recovery & $\begin{array}{c}\text { MEM/ } 1 \mathrm{~g} / 28 \mathrm{~d} / 3 \mathrm{~g} / 14 \mathrm{~d} / 3 \mathrm{~g} / 19 \mathrm{~d} \\
\text { PMB/50 mg/ } 20 \mathrm{~d} \\
\text { VAN/ } 500 \mathrm{mg} / 17 \mathrm{~d} \\
\text { GEN/ } 240 \mathrm{mg} / 9 \mathrm{~d} / 80 \mathrm{mg} / 4 \mathrm{~d} \\
\text { TEICO/ } 200 \mathrm{mg} / 24 \mathrm{~d}\end{array}$ \\
\hline 12 & $\mathrm{~F}$ & 34 & Urine culture & ND & ND & $\mathrm{C}$ & ND & ND \\
\hline 13 & $\mathrm{~F}$ & 14 & Tracheal aspirates & 15 & $\begin{array}{c}\text { RESP, NEURO, } \\
\text { PNA }\end{array}$ & C & Recovery & $\begin{array}{c}\text { PIP-TAZ/ } 4 \mathrm{~g}-0.5 \mathrm{~g} / 10 \mathrm{~d} \\
\text { AMK/ } 500 \mathrm{mg} / 3 \mathrm{~d}\end{array}$ \\
\hline 14 & $M$ & 35 & Tracheal aspirates & 15 & RESP & $\mathrm{I}$ & Recovery & AMOX+CLAV/ $500 \mathrm{mg}-100 \mathrm{mg} / 15 \mathrm{~d}$ \\
\hline 15 & $\mathrm{~F}$ & 65 & Urine culture & 30 & ND & 1 & Recovery & $\begin{array}{c}\mathrm{IMP}+\mathrm{CIS} / 500 \mathrm{mg}-500 \mathrm{mg} / 24 \mathrm{~d} \\
\mathrm{TEICO} / 400 \mathrm{mg} / 7 \mathrm{~d} \\
\mathrm{PMB} / 50 \mathrm{mg} / 20 \mathrm{~d}\end{array}$ \\
\hline
\end{tabular}


Table 1 - Clinical characteristics of 28 patients infected/colonized with carbapenem-resistant Pseudomonas aeruginosa strains. (cont)

\begin{tabular}{|c|c|c|c|c|c|c|c|c|}
\hline Patient & Gender & Age (years) & Clinical specimen & $\begin{array}{l}\text { Lenght of } \\
\text { stay (days) }\end{array}$ & Comorbidities & HAI & Outcome & Treatment \\
\hline 16 & $\mathrm{~F}$ & 70 & Tracheal aspirates & 38 & $\begin{array}{c}\text { DM, DEC, SAH, } \\
\text { SEP }\end{array}$ & $\mathrm{C}$ & Death & $\begin{array}{c}\text { MEM/ 3,000 mg/1 d/2,000 mg/6 } \\
\text { d/2,000mg/ } 14 \mathrm{~d} \\
\mathrm{IMP}+\mathrm{CIS} / 500 \mathrm{mg}-500 \mathrm{mg} / 17 \mathrm{~d} \\
\mathrm{VAN} / 2,000 \mathrm{mg} / 14 \mathrm{~d} \\
\mathrm{GEN} / 80 \mathrm{mg} / 14 \mathrm{~d} \\
\mathrm{PMB} / 50 \mathrm{mg} / 14 \mathrm{~d}\end{array}$ \\
\hline 17 & $M$ & 79 & Urine culture & 40 & $\begin{array}{l}\text { ALCOH, SAH, } \\
\text { COPD, CARD, } \\
\text { TAB, NEURO, } \\
\quad \text { SEP }\end{array}$ & I & Death & $\begin{array}{c}\text { CRO } 200 \mathrm{mg} / 5 \mathrm{~d} \\
\text { PIP+TAZ/ } 4 \mathrm{~g}-0.5 \mathrm{~g} / 3 \mathrm{~d} \\
\mathrm{MEM} 3 \mathrm{~g} / 2 \mathrm{~d} / 1.5 \mathrm{~g} / 5 \mathrm{~d} \\
\text { VAN } 2 \mathrm{~g} / 16 \mathrm{~d} \\
\mathrm{IMI}+\mathrm{CIS} / 500 \mathrm{mg}-500 \mathrm{mg} / 15 \mathrm{~d}\end{array}$ \\
\hline 18 & M & 81 & Tracheal aspirates & 30 & ND & C & Recovery & $\begin{array}{c}\text { AMP-SAM/1g+0.5 g/7 d } \\
\text { LZD/1,200 mg/2 d } \\
\text { PMB } / 50 \mathrm{mg} / 7 \mathrm{~d}\end{array}$ \\
\hline 19 & M & 76 & Urine culture & 23 & $\begin{array}{l}\text { SAH, CARD, } \\
\text { REN, }\end{array}$ & C & Death & ND \\
\hline 20 & $M$ & 35 & Tracheal aspirates & 38 & $\begin{array}{l}\text { RESP, NEURO, } \\
\text { SEP }\end{array}$ & C & Recovery & $\begin{array}{c}\text { CLI/ } 150 \mathrm{mg} / \mathrm{mL} / 7 \mathrm{~d} \\
\text { TZP/4 g-0.5 g/ } 5 \mathrm{~d} \\
\text { TEICO } / 800 \mathrm{mg} / 2 \mathrm{~d} / 400 \mathrm{mg} / 6 \mathrm{~d} \\
\mathrm{PMB} / 50 \mathrm{mg} / 22 \mathrm{~d} \\
\mathrm{SXT}+\mathrm{TMP} / 40 \mathrm{~mL} / 3 \mathrm{~d} \\
\mathrm{GEN} / 80 \mathrm{mg} / 2 \mathrm{~d} \\
\text { MEM } / 2 \mathrm{~g} / 14 \mathrm{~d} / 3 \mathrm{~g} / 12 \mathrm{~d} \\
\text { AMP-SAM/ } 1 \mathrm{~g}-0.5 \mathrm{~g} / 13 \mathrm{~d}\end{array}$ \\
\hline 21 & $M$ & 76 & Tracheal aspirates & 25 & PNA & 1 & Death & $\begin{array}{c}\text { PIP-TAZ/ } 4 \mathrm{~g}-0.5 \mathrm{~g} / 4 \mathrm{~d} \\
\text { VAN/500 mg/ } \mathrm{d} \\
\mathrm{MEM} / 1 \mathrm{~g} / 11 \mathrm{~d} \\
\mathrm{PMB} / 50 \mathrm{mg} / 5 \mathrm{~d}\end{array}$ \\
\hline 22 & $\mathrm{~F}$ & 28 & Urine culture & 30 & NEURO, SEP & $\mathrm{C}$ & Recovery & $\begin{array}{c}\text { GEN/80 mg/ } 7 \mathrm{~d} \\
\mathrm{PMB} / 50 \mathrm{mg} / 14 \mathrm{~d} \\
\mathrm{TEICO} / 400 \mathrm{mg} / 7 \mathrm{~d} \\
\mathrm{TGC} / 80 \mathrm{mg} / 7 \mathrm{~d} \\
\mathrm{MEM} / 3 \mathrm{~g} / 7 \mathrm{~d} / 6 \mathrm{~g} / 12 \mathrm{~d} \\
\mathrm{CIP} / 1,200 \mathrm{mg} / 1 \mathrm{~d} / 800 \mathrm{mg} / 11 \mathrm{~d} \\
\mathrm{SXT}+\mathrm{TMP} / 80 \mathrm{~mL} / 7 \mathrm{~d}\end{array}$ \\
\hline 23 & $M$ & 51 & Secretion culture & 13 & DM, SAH, RESP & C & Recovery & $\begin{array}{c}\text { MEM/ } 3 \mathrm{~g} / 2 \mathrm{~d} \\
\mathrm{LZD} / 1,200 \mathrm{mg} / 1 \mathrm{~d} \\
\mathrm{PMB} / 50 \mathrm{mg} / 1 \mathrm{~d}\end{array}$ \\
\hline 24 & $\mathrm{~F}$ & 21 & Urine culture & 30 & RESP, SEP & 1 & Recovery & $\begin{array}{c}\text { MEM/ } 3 \mathrm{~g} / 4 \mathrm{~d} \\
\mathrm{PMB} / 50 \mathrm{mg} / / 16 \mathrm{~d} \\
\mathrm{GEN} / 80 \mathrm{mg} / 16 \mathrm{~d}\end{array}$ \\
\hline 25 & M & 81 & Secretion culture & 28 & RESP, NEURO & $\mathrm{C}$ & Recovery & $\begin{array}{c}\text { AMP-SAM } / 1 \mathrm{~g}+0.5 \mathrm{~g} / 11 \mathrm{~d} \\
\mathrm{PMB} / 50 \mathrm{mg} / 15 \mathrm{~d}\end{array}$ \\
\hline 26 & M & 51 & Secretion culture & 30 & $\begin{array}{l}\text { RESP, SAH, } \\
\text { CARD }\end{array}$ & C & Death & $\begin{array}{l}\text { VAN } 1 \mathrm{~g} / 21 \mathrm{~d} \\
\text { MEM } 1 \mathrm{~g} / 21 \mathrm{~d}\end{array}$ \\
\hline 27 & $\mathrm{~F}$ & 48 & Secretion culture & 39 & SAH, SEP & C & Recovery & $\begin{array}{c}\mathrm{CRO} / 2,000 \mathrm{mg} / 8 \mathrm{~d} \\
\mathrm{MTZ} / 2,000 \mathrm{mg} / 7 \mathrm{~d} \\
\mathrm{IMP}+\mathrm{CIS} / 500 \mathrm{mg} / 12 \mathrm{~d} \\
\mathrm{PMB} / 50 \mathrm{mg} / 14 \mathrm{~d} \\
\mathrm{TEICO} / 800 \mathrm{mg} / 3 \mathrm{~d} / 400 \mathrm{mg} / 9 \mathrm{~d} \\
\mathrm{GEN} / 80 \mathrm{mg} / 5 \mathrm{~d} \\
\mathrm{MEM} / 3,000 \mathrm{mg} / 1 \mathrm{~d} / 2000 \mathrm{mg} / 11 \mathrm{~d}\end{array}$ \\
\hline 28 & $\mathrm{~F}$ & 1 & Secretion culture & 30 & RESP, PNA & $\mathrm{C}$ & Recovery & $\begin{array}{c}\text { CFE/3 mL/4 d/ } 4 \mathrm{~mL} / 8 \mathrm{~d} \\
\text { MEM/3.6 mL } / 10 \mathrm{~d} \\
\text { AMK/ } 1 \mathrm{~mL} / 1 \mathrm{~d} / 0.7 \mathrm{~mL} / 9 \mathrm{~d}\end{array}$ \\
\hline
\end{tabular}

Treatments: Amikacin (AMK), Amoxicillin(AMOX), Clavulanatepotassium (CLAV), Ciprofloxacin (CIP), Gentamycin (GEN), imipenen (IMP), levofloxacin (LEV), meropenem (MEM), Piperaciclin (PIP), Polimyxin B (PMB), Tigeciclin (TGC), Ampicilin + sulbactam (AMP-SAM), cefalexin ( CFE), Teicoplamin (TEICO), Metronidazole (MTZ), sulfametoxazole+ trimetropim (SXT-TMP), Vancomycin (VAN), Cilastatin (CIS), Linezolid (LZD), ceftriaxone (CRO), Clindamicin (CLI), Levofloxacin (LVX), Tazobactam (TAZ); Comorbidities: Alcoholism (ALCOH), Cancer (CANC), Cardiovascular disease (CARD), Chronic Obstructive Pulmonary disease (COPD), Decubitus ulcers (DEC), Diabetes Mellitus (DM), Hyperthroidism (HYPER), Neurological disease (NEURO), Pneumonia (PNA), Renal Failure (REN), Respiratory Failure (RESP), Systemic Arterial Hypertension (SAH), Sepsis (SEP), Tabagism (TAB); Healthcare-associated Infections (HAI): Infeccion (I), Colonization (C); ND = not detected. 
fever, changes in the frequency or color of secretions, or new radiological findings) ${ }^{13}$. Colonizers were defined as bacteria permanently or temporarily present on the skin or the mucous membranes of the patients, irrespective of the signs or symptoms of infection. The endemic level of colonization and infection by carbapenem-resistant strains per 1,000 patients-days was calculated using a previously described method ${ }^{14}$. The costs of hospitalization of the patients in ICUs were estimated using data from the Unified Health System (SUS) of Brazil. We consulted the average daily cost in the ICU by specialty, in the municipality of Dourados, Mato Grosso do Sul State, in December-2020, through the official database of Analytical Audit in SUS Hospitalizations (DATASUS).

\section{Ethical standards}

This study was conducted with the approval of the Research Ethics Committee from Universidade Federal da Grande Dourados (No 877.292/2014).

\section{RESULTS}

\section{Antimicrobial susceptibility testing}

Twenty-eight carbapenem-resistant $P$. aeruginosa strains were isolated from patients hospitalized in an ICU. All the strains exhibited resistance to IMP and MEM with MICs ranging from 32 to $\geq 128 \mu \mathrm{g} / \mathrm{mL}$ and from 8 to $\geq 128 \mu \mathrm{g} / \mathrm{mL}$, respectively. This resistance was observed in $75 \%(21 / 28)$ of the isolates for ATM (MIC range: $\geq 8$ to $16 \mu \mathrm{g} / \mathrm{mL}$ ), $68 \%$ (19/28) for GEN (MIC range: $\geq 2$ to $8 \mu \mathrm{g} / \mathrm{mL}$ ), $60 \%$ (17/28) for CAZ (MIC range: $\geq 2$ to $16 \mu \mathrm{g} / \mathrm{mL}$ ), $71 \%$ (20/28) for FEP (MIC range $\geq 2$ to $16 \mu \mathrm{g} / \mathrm{mL}$ ), $71 \%$ (20/28) for PIP (MIC range $\leq 4$ to $\geq 64 \mu \mathrm{g} / \mathrm{mL}$ ), $71 \%$ (20/28) for CIP (MIC range $\leq 0.5$ to $\geq 2 \mu \mathrm{g} / \mathrm{mL}$ ), $53 \%$ (15/28) for AMK (MIC range $\leq 8$ to $\geq 32 \mu \mathrm{g} / \mathrm{mL}$ ), 3.5\% (01/28) for CST (MIC range $\leq 1$ to $\geq 4 \mu \mathrm{g} / \mathrm{mL}$ ), and 68\% (19/28) for LEV (MIC range $\leq 2$ to $\geq 4 \mu \mathrm{g} / \mathrm{mL}$ ). Individual results are described in the Supplementary Table S1.

\section{Molecular characterization}

The $b l a_{\text {TEM }}$ gene was detected in $11 \%(3 / 28)$ of the carbapenem-resistant $P$. aeruginosa strains, $b l a_{\mathrm{KPC}-2}$ in $11 \%(3 / 28)$, and $b l a_{\mathrm{SHV}}$ in $7 \%(2 / 28)$ of the resistant strains (Table 1). The $b l a_{\mathrm{OXA}-48}, b l a_{\mathrm{OXA}-51}, b l a_{\mathrm{VIM}-1}, b l a_{\mathrm{IMP}-1}$, $b l a_{\mathrm{NDM}-\mathrm{I}}, b l a_{\mathrm{GES}-\mathrm{p}}, b l a_{\mathrm{CTX}-\mathrm{M}}, b l a_{\mathrm{SPM}}, b l a_{\mathrm{SIM}}, b l a_{\mathrm{GIM}}$, and $b l a_{\mathrm{MCR}}$ genes were not amplified. The PCR analysis of the oprD porin gene failed to amplify all the isolates (100\%) (S1). According to the SDS-PAGE results, OprD was not identified, suggesting that $\mathrm{OprD}$ was either absent or was produced at very low levels by all isolates (Table 1).

\section{Clinical data}

The carbapenem-resistant $P$. aeruginosa strains were isolated from 28 patients hospitalized in ICUs, whose median duration of stay was 34.4 days. Previously, $75 \%$ (21/28) of the patients were hospitalized in another hospital. Out of the 28 patients, $43 \%(n=12 / 28)$ were female, their ages ranging from 1 to 84 years (median 48.9). Regarding the history of comorbidities, $43 \%$ (12/28) of the patients had sepsis, 31\% (9/28) had respiratory failure, 31\% (9/28) had systemic arterial hypertension, $28.5 \%(8 / 28)$ had neurological diseases, $25 \%$ (7/28) had cardiovascular diseases, 14\% (4/28) had pneumonia, 14\% (4/28) had diabetes mellitus, $7 \%(2 / 28)$ had a smoking history, and 7\% (2/28) were alcoholic (Table 1). Carbapenem-resistant $P$. aeruginosa strains were recovered from tracheal secretions in $43 \%(12 / 28)$ of the patients, from urine in $28.5 \%(08 / 28)$ of the patients, from secretions culture in $21 \%$ $(06 / 28)$ of the patients, from blood cultures in $3.5 \%(01 / 28)$ of the patients, and from intravenous catheters in 3.5\% (01/28) of the patients. Among the carbapenem-resistant strains, $28.5 \%(8 / 28)$ were considered true pathogens (I) and $71.5 \%(20 / 28)$ were colonizers (C) (Table 1). The three most common treatment regimens used in the patients were: carbapenems (meropenem, imipenem) in $89 \%$ (25/28), polypeptides (polymyxin B) in $82 \%$ (23/28), and glycopeptides (teicoplanin, vancomycin) in 53.5\% (15/28). The mortality rate of patients infected or colonized with carbapenem-resistant $P$. aeruginosa was 39\% (11/28).

Regarding the endemicity of carbapenem-resistant $P$. aeruginosa strains, the rate of occurrence of infection and/or colonization per 1,000 patient-days in June 2016 exceeded the average incidence of colonization/ infection, as per the established alert limit (Figure 1). The acquisition rate of infection and/or colonization was 0.01 per 1,000 patient-days in May 2016, increasing to 0.03 per 1,000 patient-days in June 2016. Although initially it did not exceed the control limit, subsequent cases led the acquisition rate of carbapenem-resistant strains to rise above the mean prevalence, causing it to reach the alert limit at different times of the study period. Patients infected or colonized with carbapenem-resistant strains remained hospitalized for a minimum of 13 days. Each patient infected or colonized with carbapenem-resistant strains spent a median of US\$3.174,87 in the treatment (Brazilian reals were converted to U.S. dollars using the quotation of December 21, 2020 when R $\$ 5.22=$ US\$ 1.00 , resulting in US\$ 91.70 per day of hospitalization. 


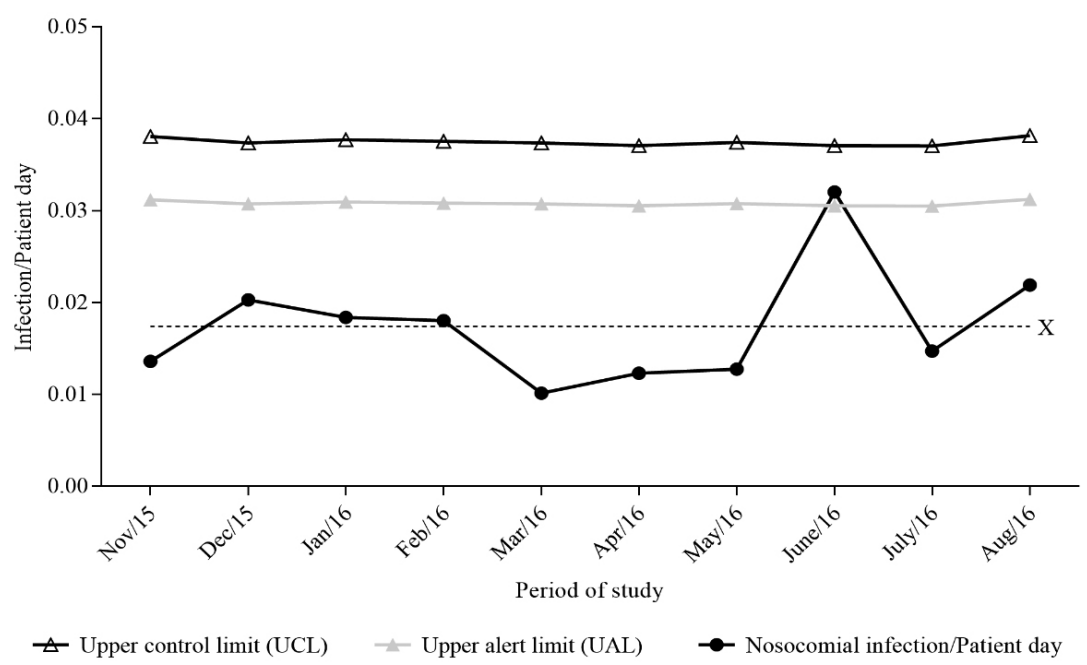

Figure 1 - Endemic level of colonization/infection due to carbapenem-resistant $P$. aeruginosa strains per 1,000 patient-days from November 2015 to August 2016. Upper control limit $(3 \sigma+\mathrm{X})$; upper alert limit $(2 \sigma+\mathrm{X})$; X: centerline (mean rate of $P$. aeruginosa strains per 1,000 patient-days).

\section{DISCUSSION}

The prevalence of antimicrobial resistance is increasing, probably due to the widespread use of carbapenems in the hospital environment. This can selectively increase the pressure on the hospital microbiota, in turn, increasing the emergence and spread of resistant bacteria; thus, affecting the morbidity and mortality of the patients ${ }^{15}$. The ICUs are the major sources of dissemination of multidrug-resistant organisms, where the selection pressure is the highest for the emergence of resistance. The nosocomial infection rate in ICUs is $2-5$ times higher than that in the general (nonICU) hospital population ${ }^{16}$. Interestingly, in our study, all carbapenem-resistant $P$. aeruginosa strains were isolated from patients hospitalized in the ICU, indicating that in this hospital, the frequency of these strains is restricted to the ICU.

Out of the 28 carbapenem-resistant $P$. aeruginosa strains evaluated, only three KPC-producing $P$. aeruginosa strains were identified. The production of carbapenemase has emerged in Brazil as the main mechanism of resistance to carbapenem among clinical isolates of $P$. aeruginos $a^{17}$. However, the low rates of KPC-producing $P$. aeruginosa observed suggest that other mechanisms could be involved in the evolution of resistance. In our study, OprD porin was absent or was produced at very low levels in carbapenemresistant $P$. aeruginosa, indicating that the loss of $\mathrm{OprD}$ has contributed to carbapenem resistance ${ }^{18}$. Sequence changes including amino acid deletions or substitutions, probably led to an increase in the minimum inhibitory concentration of carbapenems ${ }^{19}$. The emergence of resistance to $P$. aeruginosa to carbapenems associated with the loss of porin by an insertion sequence element has been associated with an increase in the MIC of imipenem and meropenem from 0.5 and $2 \mu \mathrm{g} / \mathrm{mL}$, respectively, to up to $16 \mu \mathrm{g} / \mathrm{mL}^{20}$. Several studies have reported that mutations, insertions, and/or deletions are responsible for inactivating the $o p r \mathrm{D}$ gene, therefore conferring resistance to imipenem and meropenem in clinical isolates of $P$. aeruginosa recovered worldwide ${ }^{21-27}$. Thus, the deficiency of the outer membrane protein OprD appears to be the mechanism involved in the resistance of $P$. aeruginosa strains evaluated in our study. Several mechanisms are involved in the drug resistance of P. aeruginosa ${ }^{28}$. In general, these mechanisms coexist simultaneously, conferring a combined resistance to many antibiotics, narrowing the treatment options. The intrinsic resistance involves the overexpression of efflux pumps and their low permeability to the outer membrane ${ }^{28}$, whereas the acquired resistance involves the acquisition of resistance genes or mutations in genes encoding porins, efflux pumps, penicillin-binding proteins, and chromosomal $\beta$-lactamase, all contributing to the resistance to $\beta$-lactams, carbapenems, aminoglycosides, and fluoroquinolones ${ }^{29}$.

The carbapenem-resistant $P$. aeruginosa strains were isolated from patients hospitalized in ICUs for long periods (mean 34.4 days). They had several comorbidities and poor outcomes (39\% mortality rate). The emergence of resistance during treatment is associated with increased morbidity, mortality, and health $\operatorname{costs}^{30}$. Pseudomonas aeruginosa is one of the main pathogens in ICUs ${ }^{31}$ responsible for high mortality rates, ranging from $24.8 \%$ in patients infected with sensitive $P$. aeruginosa to $44.6 \%$ in patients infected with multidrug-resistant $P$. aeruginosa ${ }^{32}$. The acquisition of carbapenem-resistance in $P$. aeruginosa strains plays an important role in the high mortality rates. However, they 
are not the only factor responsible for the poor outcomes observed in the studied patients, considering that they displayed several other unfavorable clinical conditions ${ }^{33-37}$.

Besides having negatively impacted the clinical outcomes, carbapenem resistance has also created an undue economic burden with a high cost of hospitalization (median cost of US\$ $3.174,87$, for 34.61 days) as we have demonstrated here. Previous studies showed that carbapenem resistance was a significant predictor of in-hospital mortality ${ }^{38}$ and resulted in an increase in hospital-related $\operatorname{costs}^{37}$. The resistance of $P$. aeruginosa to antimicrobials is a global problem, especially in countries with limited resources, due to the need for new treatment options and improvement of basic practices for the prevention and surveillance of infections ${ }^{39}$. In hospitals, an active surveillance for the early detection of colonized patients is necessary to prevent institutional outbreaks and to limit dissemination; the early intervention to prevent death through the administration of antimicrobials is effective in controlling the threat ${ }^{40}$.

There are, however, some limitations in our study. Firstly, it was performed in only one hospital. Thus, the prevalence and molecular characteristics of carbapenemresistant $P$. aeruginosa strains may not be generalizable across the country. In addition, we had several difficulties in determining the clinical characteristics of some patients from whom the carbapenem-resistant $P$. aeruginosa strains were isolated, so that they were excluded from the study. Excluding the limitations, our study added important data to the literature by showing that patients hospitalized in ICUs are primarily affected by carbapenem-resistant P. aeruginosa strains. Additionally, the production of carbapenemases may not be the main mechanism of resistance in $P$. aeruginosa strains circulating in the hospital.

Our results showed that alterations in OprD may be responsible for the resistance to carbapenem among $P$. aeruginosa isolated from patients hospitalized in Dourados, Brazil. Identifying the factors that can influence the mobilization and insertion of elements that disrupt the oprD gene can contribute significantly to our current knowledge of mechanisms involved in the emergence of antibiotic resistance and the evolution of $P$. aeruginosa. Additionally, stricter measures to contain the spread of multi-resistant microorganisms can contribute to the reduction of mortality of patients hospitalized in ICUs, as well as to reduce the costs of hospitalization.

\section{ACKNOWLEDGMENTS}

The authors would like to thank the Coordenação de Aperfeiçoamento de Pessoal de Nivel Superior (CAPES) and the Universidade Federal da Grande Dourados (UFGD).

\section{CONFLICT OF INTERESTS}

The authors have declared that no competing interests exist.

\section{FUNDING}

This study was supported by the Brazilian National Council for Scientific and Technological Development (grant No 151992/2020-7).

\section{REFERENCES}

1. Nordmann P, Poirel L. Epidemiology and diagnostics of Carbapenem resistance in Gram-negative Bacteria. Clin Infect Dis. 2019;69 Suppl 7:S521-8.

2. Pachori P, Gothalwal R, Gandhi P. Emergence of antibiotic resistance Pseudomonas aeruginosa in intensive care unit; a critical review. Genes Dis. 2019;6:109-19.

3. van Duin D, Kaye KS, Neuner EA, Bonomo RA. Carbapenemresistant Enterobacteriaceae: a review of treatment and outcomes. Diagn Microbiol Infect Dis. 2013;75:115-20.

4. Cai B, Echols R, Magee G, Arjona Ferreira JC, Morgan G, Ariyasu $\mathrm{M}$, et al. Prevalence of Carbapenem-resistant gram-negative infections in the United States predominated by Acinetobacter baumannii and Pseudomonas aeruginosa. Open Forum Infect Dis. 2017;4:ofx176.

5. Kim T, Lee EJ, Park SY, Yu SN, Lee YM, Park KH, et al. Natural prognosis of carbapenem-resistant Acinetobacter baumannii bacteremia in patients who did not receive appropriate antibiotic treatment: a retrospective multicenter study in Korea. Medicine (Baltimore). 2018;97:e12984.

6. Weiner LM, Webb AK, Limbago B, Dudeck MA, Patel J, Kallen AJ, et al. Antimicrobial-resistant pathogens associated with healthcare-associated infections: summary of data reported to the National Healthcare Safety Network at the Centers for Disease Control and Prevention, 2011-2014. Infect Control Hosp Epidemiol. 2016;37:1288-301.

7. Royer S, Faria AL, Seki LM, Chagas TP, Campos PA, Batistão DW, et al. Spread of multidrug-resistant Acinetobacter baumannii and Pseudomonas aeruginosa clones in patients with ventilator-associated pneumonia in an adult intensive care unit at a university hospital. Braz J Infect Dis. 2015;19:350-7.

8. Neves PR, Mamizuka EM, Levy CE, Lincopan N. Pseudomonas aeruginosa multirresistente: um problema endêmico no Brasil. J Bras Patol Med Lab. 2011;47:409-20.

9. Bassetti M, Vena A, Croxatto A, Righi E, Guery B. How to manage Pseudomonas aeruginosa infections. Drugs Context. 2018;7:212527. 
10. Clinical and Laboratory Standards Institute. Performance standards for antimicrobial susceptibility testing. 28th ed. Wayne: CLSI; 2018.

11. Neves FC, Clemente WT, Lincopan N, Paião ID, Neves PR, Romanelli RM, et al. Clinical and microbiological characteristics of OXA-23- and OXA-143-producing Acinetobacter baumannii in ICU patients at a teaching hospital, Brazil. Braz J Infect Dis. 2016;20:556-63.

12. Pai H, Kim J, Kim J, Lee JH, Choe KW, Gotoh N. Carbapenem resistance mechanisms in Pseudomonas aeruginosa clinical isolates. Antimicrob Agents Chemother. 2001;45:480-4.

13. Horan TC, Andrus M, Dudeck MA. CDC/NHSN surveillance definition of health care-associated infection and criteria for specific types of infections in the acute care setting. Am J Infect Control. 2008;36:309-32.

14. Arantes A, Carvalho ES, Medeiros EA, Farhat CK, Mantese OC. Uso de diagramas de controle na vigilância epidemiológica das infecções hospitalares. Rev Saude Publica. 2003;37:76874.

15. Wang TZ, Kodiyanplakkal RP, Calfee DP. Antimicrobial resistance in nephrology. Nat Rev Nephrol. 2019;15:463-81.

16. Ribeiro AC, Crozatti MT, Silva AA, Macedo RS, Machado AM, Silva AT. Pseudomonas aeruginosa in the ICU: prevalence, resistance profile, and antimicrobial consumption. Rev Soc Bras Med Trop. 2020;53:e20180498.

17. Balero de Paula S, Cayô R, Streling AP, Silva Nodari C, Pereira Matos A, Eches Perugini MR, et al. Detection of bla(VIM-7) in an extensively drug-resistant Pseudomonas aeruginosa isolate belonging to ST1284 in Brazil. Diagn Microbiol Infect Dis. 2017;89:80-2.

18. Campana EH, Xavier DE, Petrolini FV, Cordeiro-Moura JR, Araujo MR, Gales AC. Carbapenem-resistant and cephalosporin-susceptible: a worrisome phenotype among Pseudomonas aeruginosa clinical isolates in Brazil. Braz J Infect Dis. 2017;21:57-62.

19. Ochs MM, Bains M, Hancock RE. Role of putative loops 2 and 3 in imipenem passage through the specific porin OprD of Pseudomonas aeruginosa. Antimicrob Agents Chemother. 2000;44:1983-5.

20. Fowler RC, Hanson ND. Emergence of Carbapenem resistance due to the novel insertion sequence ISPa8 in Pseudomonas aeruginosa. PloS One. 2014;9:e91299.

21. Mirsalehian A, Kalantar-Neyestanaki D, Taherikalani M, Jabalameli F, Emaneini M. Determination of carbapenem resistance mechanism in clinical isolates of Pseudomonas aeruginosa isolated from burn patients, in Tehran, Iran. J Epidemiol Glob Health. 2017;7:155-9.

22. Richardot C, Plésiat P, Fournier D, Monlezun L, Broutin I, Llanes C. Carbapenem resistance in cystic fibrosis strains of Pseudomonas aeruginosa as a result of amino acid substitutions in porin OprD. Int J Antimicrob Agents. 2015;45:529-32.
23. Tsai MH, Wu TL, Su LH, Lo WL, Chen CL, Liang YH, et al. Carbapenem-resistant-only Pseudomonas aeruginosa infection in patients formerly infected by carbapenem-susceptible strains. Int J Antimicrob Agents. 2014;44:541-5.

24. Xavier DE, Picão RC, Girardello R, Fehlberg LC, Gales AC. Efflux pumps expression and its association with porin downregulation and beta-lactamase production among Pseudomonas aeruginosa causing bloodstream infections in Brazil. BMC Microbiol. 2010;10:217.

25. Rodríguez-Martínez JM, Poirel L, Nordmann P. Molecular epidemiology and mechanisms of carbapenem resistance in Pseudomonas aeruginosa. Antimicrob Agents Chemother. 2009;53:4783-8.

26. Sun Q, Ba Z, Wu G, Wang W, Lin S, Yang H. Insertion sequence ISRP10 inactivation of the oprD gene in imipenem-resistant Pseudomonas aeruginosa clinical isolates. Int J Antimicrob Agents. 2016;47:375-9.

27. Zeng ZR, Wang WP, Huang M, Shi LN, Wang Y, Shao HF. Mechanisms of carbapenem resistance in cephalosporinsusceptible Pseudomonas aeruginosa in China. Diagn Microbiol Infect Dis. 2014;78:268-70.

28. Pang Z, Raudonis R, Glick BR, Lin TJ, Cheng Z. Antibiotic resistance in Pseudomonas aeruginosa: mechanisms and alternative therapeutic strategies. Biotechnol Adv. 2019;37:17792.

29. Botelho J, Grosso F, Peixe L. Antibiotic resistance in Pseudomonas aeruginosa: mechanisms, epidemiology and evolution. Drug Resist Updat. 2019;44:100640.

30. Yusuf E, Van Herendael B, Verbrugghe W, Ieven M, Goovaerts E, Bergs K, et al. Emergence of antimicrobial resistance to Pseudomonas aeruginosa in the intensive care unit: association with the duration of antibiotic exposure and mode of administration. Ann Intensive Care. 2017;7:72.

31. Costa DM, Johani K, Melo DS, Lopes LK, Lopes Lima LK, Tipple $\mathrm{AF}$, et al. Biofilm contamination of high-touched surfaces in intensive care units: epidemiology and potential impacts. Lett Appl Microbiol. 2019;68:269-76.

32. Matos EC, Andriolo RB, Rodrigues YC, Lima PD, Carneiro IC, Lima KV. Mortality in patients with multidrug-resistant Pseudomonas aeruginosa infections: a meta-analysis. Rev Soc Bras Med Trop. 2018;51:415-20.

33. Li S, Jia X, Li C, Zou H, Liu H, Guo Y, et al. Carbapenem-resistant and cephalosporin-susceptible Pseudomonas aeruginosa: a notable phenotype in patients with bacteremia. Infect Drug Resist. 2018;11:1225-35.

34. Machuca I, Gutierrez-Gutierrez B, Gracia-Ahufinger I, Rivera Espinar F, Cano A, Guzmán-Puche J, et al. Mortality associated with bacteremia due to Colistin-resistant Klebsiella pneumoniae with high-level meropenem resistance: importance of combination therapy without Colistin and Carbapenems. Antimicrob Agents Chemother. 2017;61:e00406-17. 
35. Li S, Jia X, Li C, Zou H, Liu H, Guo Y, et al. Carbapenem-resistant and cephalosporin-susceptible Pseudomonas aeruginosa: a notable phenotype in patients with bacteremia. Infect Drug Resist. 2018;11:1225-35.

36. Ozsurekci Y, Aykac K, Cengiz AB, Basaranoglu ST, Sancak B, Karahan S, et al. Bloodstream infections in children caused by carbapenem-resistant versus carbapenem-susceptible Gramnegative microorganisms: risk factors and outcome. Diagn Microbiol Infect Dis. 2017;87:359-64.

37. Rao YB, Ren ZX, Zhong JJ, Zhong XM, Cao B, Chen DM, et al. Risk factors for imipenem-resistant Pseudomonas aeruginosa in neonatal intensive care units in south China. J Hosp Infect. 2018;98:305-8.
38. Judd WR, Ratliff PD, Hickson RP, Stephens DM, Kennedy CA. Clinical and economic impact of meropenem resistance in Pseudomonas aeruginosa-infected patients. Am J Infect Control. 2016;44:1275-9.

39. Rosenthal VD, Al-Abdely HM, El-Kholy AA, AlKhawaja SA, Leblebicioglu $\mathrm{H}$, Mehta $\mathrm{Y}$, et al. International Nosocomial Infection Control Consortium report, data summary of 50 countries for 2010-2015: device-associated module. Am J Infect Control. 2016;44:1495-504.

40. Codjoe FS, Donkor ES. Carbapenem resistance: a review. Med Sci (Basel). 2017;6:1.

Supplementary Material available from: https://doi.org/10.48331/scielodata.0NICXF 